\title{
RESILIENCE IN REMARRIED FAMILIES
}

\section{CARIEN DU TOIT-GOUS}

Assignment presented in partial fulfilment of the requirements for the degree of Master of Arts (Counselling Psychology) at the University of Stellenbosch

Supervisor: Prof A P Greeff

April 2005 


\section{STATEMENT}

I, the undersigned, hereby declare that the work contained in this assignment is my own original work and, that I have not previously in its entirety or in part submitted it at any university for a degree. 


\section{ABSTRACT}

Using a cross-sectional survey research design the present study aims to explore those resilience factors which enable remarried families to withstand and rebound from the disruptive challenges they face. Furthermore, recovery factors were examined which enabled remarried families to cope more effectively and to emerge hardier from a crisis. Remarried families who were married between one to four years, with at least one family member presently in school, were approached to take part in this study. A parent and a child from 38 families independently completed six questionnaires and an open-ended question. It is proposed that the most important resilience factors identified in this study, through qualitative and quantitative measures, include (1) family relationships and support (mutual respect, cooperation and a loving bond), (2) family communication that is affirming, conveying care and support, as well as less incendiary communication that tends to exacerbate a stressful situation, (3) the ability to have a sense of control over outcomes in life by having a active orientation in adjusting to and managing stressful situations, (4) activities and routines that helps the family in spending time together and creating togetherness, (5) a strong marriage relationship (consisting of clearly defined roles, equality and support for each other), (6) support from family and friends, (7) internal and external handling of problems by redefining stressful events and acquiring and accepting social support, (8) spirituality and religion within the family that provides meaning and purpose beyond a crisis situation. 


\section{OPSOMMING}

' $n$ Dwarssnit navorsingsontwerp is gebruik om veerkragtigheidsfaktore te identifiseer wat hersaamgestelde gesinne in staat stel om weerstand te bied in ontwrigtende uitdagings wat hulle in die gesig staar. Verder is herstellingsfaktore ondersoek wat hersaamgestelde gesinne in staat stel om 'n krisis effektief te hanteer. Hersaamgestelde gesinne wat tussen een tot vier jaar getroud is, met ten minste een gesinslid op skool, is genader om aan die studie deel te neem. ' $n$ Ouer en 'n kind van 38 gesinne het onafhanklik ses vraelyste en ' $n$ oop-end vraag beantwoord. Die volgende veerkragtigheidsfaktore is met behulp van kwalitatiewe en kwantitatiewe metings geïdentifiseer: (1) gesinsverhoudings en ondersteuning (wedersydse respek, samewerking en ' $n$ liefdevolle band), (2) oop gesinskommunikasie wat bevestigend is en wat sorg en ondersteuning oordra, sowel as minder opruiende kommunikasie wat geneig is om stresvolle situasies te vererger, (3) die vermoë om ' $n$ sin van kontrole oor uitkomste in die lewe te hê deur 'n aktiewe orientasie in aanpassing tot en die beheer van stresvolle situasies, (4) aktiwiteite en roetine wat gesinne help om tyd saam te spandeer en die skep van samesyn, (5) 'n sterk huweliksverhouding (bestaande uit duidelike gedefinieerde rolle, gelykheid en ondersteuning van mekaar), (6) ondersteuning van familie en vriende, (7) interne en eksterne hantering van probleme deur die herdefiniëring van stresvolle gebeure, sowel as die verkryging en aanvaarding van sosiale ondersteuning, (8) spiritualiteit en godsdiens in die gesin wat doel en betekenis verskaf wat verder gaan as die krisissituasie. 


\section{ACKNOWLEDGEMENTS}

\section{"Coram Deo"}

For the development of this article I feel a deep sense of gratitude to

- My husband, Gerhard Gous, for his unconditional love and beliexf in me.

- My parents, Pieter en Marie du Toit, for their continuous investment, love and support in my life.

- Pierre du Toit, my brother, for his support and always believing that I could do anything I set my mind to.

- Prof. A. Greeff my supervisor, his expertise, encouragement and what he has taught me have enriched my life.

- Dr Kidd for his assistance with the statistics.

- All the remarried families that took part in this study. 


\section{CONTENTS}

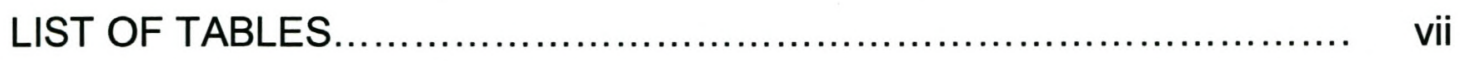

INTRODUCTION................................................................. 1

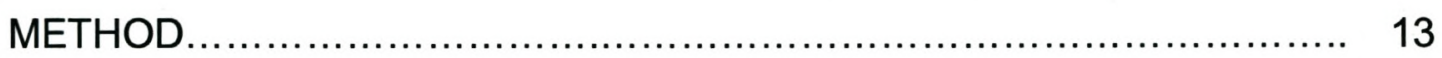

Participants............................................................. 13

Measuring Instruments............................................ 14

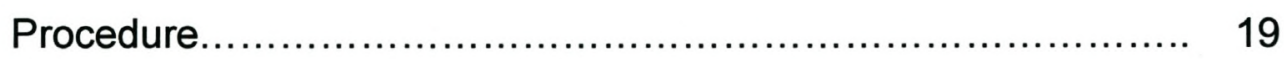

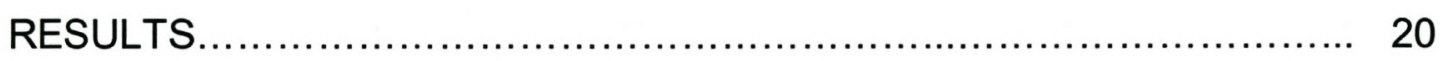

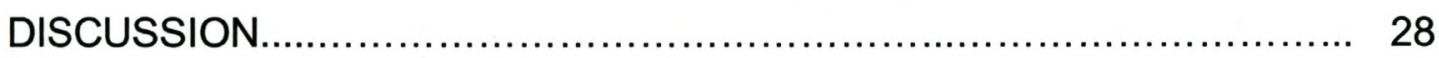

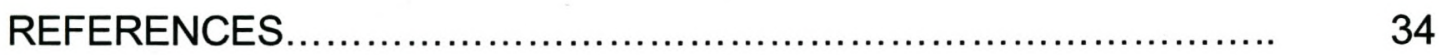




\section{LIST OF TABLES}

Page

1. Internal and External Coping Resources as Reported by the

Parents $(\mathrm{N}=38)$

2. Pearson Product-Moment Correlations between Family Attachment 22 and Changeability (FACl8) and Potential Resiliency Variables

3. Regression Analysis for Family Adaptation (FACl8) as Dependent 25

Variable vs. Potential Resiliency Variables (parents) $(\mathrm{N}=38)$

4. Regression Analysis for Family Adaptation (FACl8) as Dependent 26

Variable vs. Potential Resiliency Variables (children) $(n=21)$ 


\section{INTRODUCTION}

Family life has changed dramatically over the ages and the 21 st century will be characterised as the era of family transformation and stress. Professional literature forecast the death of the family consisting of a husband, wife, and their children (Lauer, 1989). There is a widespread sense of confusion about the meaning and structure of family relationships - regarding what is "normal" in family life and how "healthy" families are constructed (Walsh, 1998a).

Divorce and diverse family forms is a common phenomenon and remarriage describes a far more complex set of relationships than was true a few generations ago. The phenomenon of divorce is something most people do not plan to happen to them and the breakdown of marriage initiates a series of notable changes in the lives of parents and children and becomes a wrenching experience (Kalter, 1990). Parents often become physically and emotionally absent during separation and divorce and often struggle to provide their children with attention, caring and the supervision that they need (Reivich \& Shatte, 2003). Therefore, remarriage is not merely a short-term single event, but a complex set of changing conditions escalating from pre-divorce tensions, through separation and reorganisation of households and parent child relationships, and again with remarriage and stepfamily integration (Walsh, 2003b). This study aims to examine the concept of family resilience and to explore how family resilience influences the adjustment and adaptation of a reconstituted family after remarriage.

Stepfamilies in America have multiplied to the point that they have been designated as the fastest growing family configuration (Berger, 1995; Gold, Bubenzer \& West, 1993). It is estimated that one in every two couples in the United States of America will eventually divorce (Derma, 1999). According to the South African 
Population Census almost a tenth of the people who were married between 1996 and 2001 had separated or were divorced (Stats SA, 2001). Furthermore, divorce is higher in subsequent marriages than in first marriages (Hetherington, 1989).

Stepfamilies are created by a remarriage into which one or both spouses have at least one child from a previous marriage (Berger, 1995). Remarriage means that families are in transition from life in their former households to an integrated stepfamily, a process that usually takes some time (Visher, Visher \& Pasley, 2003).

"The remarried family systems are defined as a network of people and relationships created through the prior divorce and the formalisation of the remarriage. These include the former spouses of one or both the remarriage adults, the families of origin of all adults, the remarriage couple and their former spouses and the children of each of the adults" (Messinger, $1984 \mathrm{p}$. 152).

Remarried families are thus different from the context of the first marriage, as they have additional challenges they need to accomplish (Swenson, 1997). The period of restructuring and reorganising through which a remarried family passes, consists of moving from the first marriage, through divorce and subsequently two household families establishing a remarriage (Whiteside, 1982). This process is very complicated in that a new family is formed that originates from the integration of two, and sometimes even three, different families. Other processes that influence this integration would be (1) experiences of the previous marriage are carried through into the subsequent ones, (2) continued contact with the former spouse, (3) difference in personal maturity, life experience and social status, and (4) different norms and expectations (Swenson, 1997). 
Research indicates that remarried individuals have lower levels of general "wellbeing", are more likely to report multiple stressors, experiencing more emotional problems that require professional assistance, more health problems and the presence of stepchildren increases the possibility that a remarriage may end in divorce (Fine \& Schwebel, 1992). It is, therefore, of the utmost importance that psychologists understand and acknowledge the complexities of remarriage and the influences this has on the stepfamily system (McGoldrick \& Carter, 1989).

A remarriage developmental sequence was developed, which describes the significant disruption and changes that a remarried family endures (Whiteside, 1982). The stages consists of: (1) first married family, (2) a period of parting which includes marital separation, (3) divorce, and the establishment of two separate households, (4) a courting period with plans for remarriage, (5) early remarriage; and then established remarriage (Whiteside, 1982). An understanding of the pain of transition needs to be considered. The formation of stepfamilies takes time and effort on the part of all the individuals in the family. Visher and Visher (1990) identified four tasks with which stepfamilies need to deal in order to be satisfied with their new family constellation. These include the development of an effective and sound new couple relationship, the maintenance of the parent-child bonds that existed previously, the formation of new step relationships, and finally the development of a sense of membership in the new family unit. To be successful, the majority of these challenges have to be dealt with to create satisfaction in the new household and family.

As divorce rates increase and remarriage becomes increasingly more common, it is imperative that we have an understanding of the processes associated with the above. Research of this nature could add to our understanding why some families 
are more resilient during the adaptation process and how they embrace challenges, such as remarriage. In investigating the resilience of remarried families, we need to focus on the strengths of families, rather than the pathology. An increasing number of researchers are distancing them from the view that single parent and stepfamilies are atypical or pathogenic, and include divorce and remarriage as a common phenomenon in the family life cycle (Visher \& Visher, 1990).

According to Hawley and DeHaan (1996) the salutogenic orientation developed by Antonovsky is concerned with discovering characteristics that contribute to healthy functioning families, rather than looking at factors associated with deficits. In terms of remarriage this is a particularly useful approach as stepfamilies were traditionally viewed in a negative light (Hawley \& DeHaan, 1996). If the focus in society is amended to concentrate on strengths, these families will be affirmed, it will enhance their family functioning and in turn strengthen their resilience. As a construct resilience seems to be a fitting description, since remarried families are then able to construct something better, new and healthy (Shirley, 2000).

A redirection of inquiry and response is, therefore, required. Instead of regarding clients as an amorphous mass of deficits, a resiliency perspective "affirms the family's capacity for self-repair" (Walsh, 1996). The concept of family resilience is a valuable framework to pave the way to guide research, intervention, and prevention efforts in adverse conditions (Von Eye \& Schuster, 2000). While crises or persistent stressors shatter some families, other emerge strengthened and more resourceful (Walsh, 1996). By using a resilience-based approach, key interact ional processes are identified and fortified that enable families to withstand and rebound from crisis and challenge (Walsh, 1998b). There is something "innately appealing about 
studying resilience" because it addresses ways in which families are successful, rather than ways in which they fail (Hawley \& DeHaan 1996, p. 285).

Family resilience is a relatively new construct that describes how families adapt to stress and bounce back from adversity (Silliman, 1994). The growing interest in the concept of resilience exhibited during the waning years of the $20^{\text {th }}$ century accelerated dramatically (Ganong \& Coleman, 2002). Most research to date focused on resilience among individuals and these studies are well established in developmental psychopathology (Hawley, 2000; Walsh, 2003a). Resilience has been commonly used by clinical or developmental psychologists and psychiatrists who were interested in how children and adolescents overcame adversity in their lives (Luthar, Cicchetti \& Becker, 2000; Masten, 2001). A resiliency lens shifts the perspective from viewing families as challenged and not damaged, and this shift affirms their reparative potential (Walsh, 2003b). This approach is based on the conviction that both individual and family growth could be forged by means of collaborative efforts in the face of adversity (Walsh, 1996; 1998b). Three clinical implications of adopting such a mindset in therapy have been distinguished:

- a focus on strengths, recognising resilience as a developmental pathway,

- a search for commonalties among diverse paths of resilience, and

- an emphasis on helping families develops a useful family schema (Hawley, 2000).

Resilience is described in developmental literature in numerous ways. At the most basic level, resilience refers to positive adaptation patterns in the context of significant risk or adversity (Masten \& Powell, 2003). The concept of resilience refers to efforts to maintain or restore internal or external equilibrium under significant threat by means of human activities, including thoughts and action (Riolli, Savicki \& Cepani, 2002). Resiliency combines the interaction of risk factors - stressful life events or 
adverse environmental conditions that increase the vulnerability of individuals - and the presence of personal, familial, and community protective factors that buffer and protect against those vulnerabilities (Norman, 2000). Luthar et al. (2000) defines resilience as: "A dynamic process encompassing positive adaptation within the context of significant adversity" (p. 243). Many of these definitions encompass several themes. First, resilience surfaces in the face of hardship. It involves the manner in which individuals respond to difficulties, and consequently, without struggle resilience does not emerge. Second, resilience carries a property of buoyancy. It assumes that individuals exhibiting resilience are able to "bounce back" or "rebound" from adversity, reaching or surpassing a person's crisis level of functioning. Finally, resilience is generally described in terms of wellness rather than pathology (Hawley \& DeHaan, 1996). Increasingly resilience is being viewed as a family level construct. There are multiple descriptions of family resilience in the literature. According to McCubbin and McCubbin (1988) family resilience refers to the dimensions, characteristics, and features of families which help them to be (1) resistant to disruption in the face of change and (2) adaptive in the face of crisis situations. Walsh (1996) approached this subject systemically, introducing the notion of relational resilience. This concept also focuses on the family as a functional unit. She proposed that relational resilience emphasises family processes and described the manner in which families link these processes to the unique challenges. Walsh (1996) also suggests that:

"Relational resilience incorporates a developmental perspective concerned with how a family deals with stress over time. Thus, the pathway each family takes to resilience is unique, negating the possibility of discovering a "blueprint for any singular model of 'the resilient family'" (p. 269). 
Robinson (2000) points out that Walsh affirms the multiple strengths of family systems and creatively shifts the concept of resiliency to the family as a social unit. Thus the definition is expanded beyond individual traits and capacities. A potent source of resiliency exists in the relational dynamics of the family and could be enhanced by attending to family transactions that contribute to improved adaptation, communication, collaborative problem-solving and family cohesion (Walsh, 1998a).

A focus on resilience accordingly highlights family strengths, particularly the individual, familial as well as community resources that allow family members to respond with what McCubbin and McCubbin term bonadaptation. Simultaneously this approach also provides better insight into the lives of those families who do not adapt well (Golby \& Bretherton 1999). Family resilience has been conceptualised in a number of ways (Golby \& Bretherton, 1999; McCubbin, 1988; McCubbin, Thompson, \& McCubbin, 1996): Firstly, the pre-crisis ABCX framework of Hills emphasises the A (stressor), B (resource), and C (definition of the stressor) which mediates and protects families in crisis situations (X). Secondly, studies that focus on pre- and post-crisis factors from adversities are reflected in the Double ABCX and the FAAR (Family Adjustment and Adaptation Response) Model developed by McCubbin and Patterson (McCubbin et al.,1996). The double ABCX model focuses on factors of coping and social support, which facilitates the family adaptation to a crisis situation. The FAAR model evolved as an extension of the Double ABCX and describes the process involved in the family's efforts to balance demands and resources. Thirdly, the Typology Model of Family Adjustment and Adaptation developed by McCubbin and McCubbin (McCubbin et al., 1996) provides added emphasis to the family patterns of functioning and their role in adjustment and adaptation in the face of adversity and crisis. The most recent version, the 
Resiliency Model of Family Stress, Adjustment and Adaptation, was used as the theoretical basis in the present study. Consisting of the family stress and conceptual framework and the expanded $A B C X$ adaptation phase, the Resilience Model of Family Stress, Adjustment and Adaptation includes family type (regenerative, rhythmic, and resilient families) and schema (the family's shared values, goals, priorities, expectations, and world view) to determine the level of adaptation to stressors that families achieve (Hawley \& DeHaan, 1996).

The Resiliency Model (McCubbin \& McCubbin, 1996) consists of two related phases of a family's responses to stress. (1) The adjustment phase describes the family's pre-crisis functioning and the influence of protective, or resistance factors (McCubbin, McCubbin, Thompson, Han \& Chad, 1997). When the family is faced by normative stressors, strain and transition, the family makes minor short term adjustments to manage the relevant demands with the least possible amount of disruption to the family structure (Der Kinderen \& Greeff, 2003). When these adjustments become insufficient to meet the demands, the family enters a crisis, and structural changes are needed to restore stability (Walsh, 1996; Der Kinderen \& Greeff, 2003). (2) Upon the advent of a family crisis, the family enters into the adaptation phase. This phase involves the function of recovery factors, referring to the family's ability to adapt in a family crisis situation (McCubbin et al., 1997). This requires the family to adapt to its new situation by changing its structure and internal functioning in order to restore and achieve stability (Der Kinderen \& Greeff, 2003). According to McCubbin et al. (1996) the adaptation process also consists of changing the family relationships to the environment and the community, in order to restore the family's harmony, well-being and balance. 
According to McCubbin et al. (1997) the following ten general resiliency factors (protective and recovery) emerged in the 25 years of research on families under stress. These factors are family problem-solving, communication, equality, spirituality, flexibility, truthfulness, hope, family hardiness, family time and routine, social support and health.

According to Silliman (1994) resiliency factors commonly identified in research reveal that commitment, cohesion, adaptability, communication, spirituality, connectedness, time together, and efficacy are necessary for considering resilience in families. In addition to these eight components, Silliman also found that individual resiliency traits often allow persons to survive even within dysfunctional systems. Furthermore, community factors also play a critical role in the support and development of family strength (Silliman, 1994).

Cohesion and adaptability in post-divorce remarried and first married families were investigated by Waldren, Bell, Peek and Sorell (1990). They established that high levels of cohesion and adaptability in stepfamilies were associated with low levels of stress. Secondly, the relationship between cohesion and adaptability was stronger for stepfamilies than for first married families. And thirdly the authors concluded that adaptability and cohesions patterns of relationship were similar for stepfamilies and first married families.

Messinger (1984) focused on remarried families and found that family life could stabilise and be as rewardingly compatible as first married families. The realistic attitudes of the new partners as from the beginning of their relationship, would also determine progress in the process of adaptation. It takes time to work out the functions, roles and relationships among parents, stepparents and children. Any hopes for an instant blended family co-existing in an atmosphere of love, may well 
create some disappointments. It was evident that compromise and flexibility constitute the essential ingredient if all family members are to feel that they belong to their new family.

According to Walsh (1998b) resilient families commonly emerge from crises with a sense of purpose and a heightened moral compass. Core beliefs and spiritual connections provide meaning and purpose to families in crisis situations. Considerable research evidence documents the effect of optimistic orientations and transcendent beliefs in coping with stress and crises. Resilience may be conveyed by (1) encouraging family beliefs systems, (2) community environment that increases hope and possibilities, (3) building collaboration and mutual support, (4) offering a perspective that adversity is to be expected as a normal part of life, and (5) convictions regarding families' self-worth and potential.

Economic hardship and the challenges of major life transitions from childhood to adolescence and from adolescence to early adulthood may represent particularly stressful events for families. A study conducted by Conger and Conger (2002) on resilience in Midwestern families indicated that resilience during economic adversity was promoted by marital support, problem solving skills, and a sense of mastery.

Mederer (1999) studied the resilience in American north eastern commercial fishing families. The results suggested that their ability to adjust played a major role in dealing with stress. Furthermore, communication, effective financial management, hardiness, social support, relaxation, routine and tradition were identified as core resilient factors.

Research by Hetherington and Elmore (2003) on risk and resilience in children coping with their parents' divorce and remarriage, found that children and adults in divorced and remarried families evidenced more problems in family relations and 
personal adjustment than those in non-divorced families. They also found that the vast majority of children were resilient and able to cope with their new life situations. Protective factors that buffer children from stresses were an easy temperament, internal locus of control, active coping styles, low family conflict, supportive relationships within the family, and positive relationships outside of the family with school personnel, mentors and peers.

In South Africa family resilience research is a relatively recent topic. The study of resilient families and the development of programmes to support families in South Africa are at an important crossroad. Most family resilience literature emanates from the USA, and reliable and valid research is needed to assist families and the future well-being of families in this country. To date three South African studies have been published on family resilience. Der Kinderen and Greeff (2003) explored resilience among families where a parent accepted a voluntary teacher's retrenchment package. The results highlighted the relationship between family stressors, family strain and family distress, implying that if stressors are not managed, these could lead to family tension and stress. Financial security and social support was highlighted as resilience variables. Research on resilience in families in which a parent has died (Greeff \& Human, 2004) aimed to identify those resiliency factors that enable families to adjust after the loss of a parent. It was found that intrafamilial support and family hardiness contributed to resilience within the family. Furthermore, individual characteristics, support from the extended family and religious and spiritual beliefs and activities, facilitated adjustment in families experiencing the loss of a parent. Greeff and Van der Merwe (2004) focused on variables associated with resilience in divorced families. Factors identified in this study that promoted resilience in post-divorced families consisted of (1) intra-family support, (2) support 
by the extended family, (3) support of friends, (4) religion, (4) open communication amongst family members, and (5) work and financial security.

The available literature reveals that very little research has been done on the factors associated with family resilience after remarriage. Thus the challenge is twofold in conducting future research, namely, to identify basic systemic processes that foster family resilience, while also being mindful of the diversity of family challenges and multiple routes in healthy functioning (Walsh, 1996).

In conclusion, from the literature several coping behaviours in families were identified, including adaptability, flexibility, communication, social support, and spending time together to facilitate adjustment and adaptation in families. Using the Resiliency Model of Family Stress, Adjustment and Adaptation (McCubbin et al., 1996) as a theoretical departing point, this study aims at documenting those variables that may foster family resilience in remarried families. 


$$
\& 621
$$


Stellenbosch University http://scholar.sun.ac.za
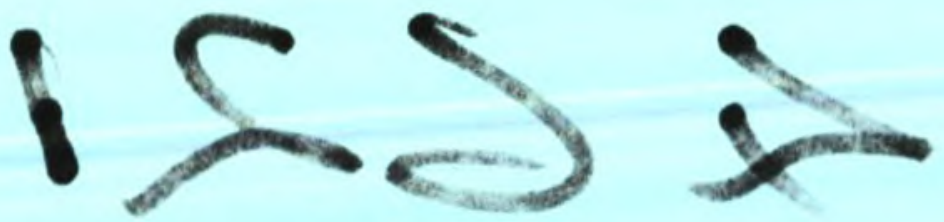


\section{METHOD}

A cross-sectional survey research design was used to identify and describe family resilience factors. Self-report questionnaires were completed by a remarried parent and a child as representatives of the family.

\section{Participants}

Fourth year postgraduate Psychology students at the University of Stellenbosch, who were enrolled for the Family Psychology module in 2002 and 2003, had to identify remarried families who fulfilled the inclusion criteria, and approach them for participation in the research project. A total of 38 families living in the Western Cape participated in this investigation. All of the identified families fulfilled the following inclusion criteria:

- Remarriage between one and four years ago

- At least one spouse's second (or subsequent) marriage

- At least one child presently in school

- No major changes in work or the environment

The home language of the participating families was as follows: $25(65.7 \%)$ were Afrikaans speaking and $13(34.2 \%)$ were English speakers. The majority of the participating parents were female $(n=34 ; 89.4 \%)$ and $10.5 \%(n=4)$ were male. The mean age of the parents participating was 42.6 years $(S D=5.25)$. Of the participating children $12(57.1 \%)$ were girls and $9(42.8 \%)$ were boys. The average age of the children was 16.4 years $(S D=4.7)$. The mean length of the current marriage was 3.4 years $(S D=2.17)$. There was an average of 2.8 children per family $(S D=1.5)$. The majority of the males $(n=28 ; 73.6 \%)$ were in their second marriage and $13.1 \%(n=5)$ in their third marriage, compared to the $60.5 \%(n=23 \%)$ of females in their second marriage and $7.8 \%(n=2)$ in their third marriage. The majority of the participants had 
a tertiary diploma $(n=15 ; 39.4 \%)$ or a degree $(n=9 ; 23.6 \%)$, or other qualifications $(n=4 ; 10.5 \%)$, seven $(18.4 \%)$ had completed their high school education and three $(7.8 \%)$ had only a primary school education. Of the spouses the majority had a tertiary diploma $(n=14 ; 36.8 \%)$ or a degree $(n=10 ; 26.3 \%)$, or other qualifications $(n=5 ; 13.1 \%)$, seven $(18.4 \%)$ had completed their high school education and two (5.2\%) had only a primary school education. The majority of the participants had a permanent job $(n=29 ; 76.3 \%)$, four $(10.5 \%)$ had a part-time job, three $(7.8 \%)$ were unemployed and two (5.2\%) were pensioners. The majority of the spouses had a permanent job $(n=30 ; 78.9 \%)$, six $(15.7 \%)$ had a part-time job, one $(2.6 \%)$ was unemployed and one $(2.6 \%)$ was a pensioner. Of the families participating in this study, two (5.5\%) reported an income of under R20 000 per annum. Of the remaining, two (5.5\%) earned between R21 000 and R40 000; three (8.3\%) earned between R41 000 and R60 000; two (5.5\%) earned between R61 000 and R80 000; six (16.6\%) earned between R81 000 and R100 000; and 21 (58,3\%) earned more than R101 000 per annum.

\section{Measuring Instruments}

A biographical questionnaire with an open-ended question was compiled to gather information regarding family composition, employment, level of education, as well as the income, age and gender of the respondent's nuclear family members. The openended question investigated the respondent's opinion on which factors or strengths they believed helped their family through the stressful period of adaptation in their new marriage.

The Family Hardiness Index (FHI) developed by McCubbin, McCubbin and Thompson measures families hardiness that refers to the ability to have a sense of control over outcomes of life and having a active orientation in adjusting to and 
managing stressful situations (McCubbin et al., 1996). Family hardiness refers to the families' sense of control and influence they have over problems and their shared commitment to work together (McCubbin et al., 1997). Family hardiness is characterised by (1) control, which refers to the belief to influence events, (2) commitment amongst family members to approach life with a sense of meaningfulness, and (3) challenge referring to change as a normal and stimulating developmental activity amongst family members (Cooper \& Payne, 1991). The scale is a 20 -item instrument that measures characteristics of hardiness as a stress resistance and adaptation resource in families to adjust and adapt to the effects of stressors and demands. The scale consists of three subscales: (1) commitment subscale measures the families sense of internal strengths, dependability and ability to work together, (2) challenge subscale measures the families' effort to be innovative, to learn and experience new things, and (3) control subscale measures the families' sense of being in control of family life rather than being shaped by outside events and circumstances (McCubbin et al., 1996). Each item assesses on a 4 point Likert rating scale the degree to which each statement describes their current family situation as either False, Mostly false, Mostly true, True or Not applicable (McCubbin et al., 1996). The internal reliability of the Family Hardiness Index (FHI) is .82 (Cronbach's alpha), and the validity coefficient ranges from .20 to .23 with criterion indices of family flexibility, satisfaction, and time and routine (McCubbin et al., 1996). The Cronbach alpha reliability coefficient of the Family Hardiness Index (FHI) in this study was .60 (Commitment, .75; Challenge, .66 and Control, .71).

The Relative and Friend Support Index (RFS) developed by McCubbin, Larsen and Olson, measures the degree to which the family uses friends and family support to manage stressors and strains (McCubbin et al., 1996). The 8 item scale requires 
a response on a 5 point Likert rating scale raging from, strongly disagree to strongly agree (McCubbin et al., 1996). The scale has an internal reliability of .82 (Cronbach's alpha) and a validity coefficient of .99 (correlation with the original Family Crises Oriented Personal Evaluation Scales [F-COPES]) (McCubbin et al., 1996). The Cronbach alpha reliability coefficient of the Relative and Friend Support Index (RFS) in this study was .71.

The Social Support Index (SSI), developed by McCubbin, Patterson and Glynn, (McCubbin et al., 1996), evaluated the importance of finding support in the community and the families' integration in the community (McCubbin et al., 1996). According to Greeff and Human (2004) the support from the communities could be emotional (recognition and affirmation), esteem support (affection), and network support (relationships with relatives). This 17 item instrument is rated on a five point scale of agreement, ranging from "strongly disagree" to "strongly agree" (McCubbin et al., 1996). The internal reliability of the Social Support Index measures .82 (Cronbach's alpha) and the validity coefficient (correlation with the criterion of family well-being) was .40 (McCubbin et al., 1996). The Cronbach alpha reliability coefficient of the Social Support Index in this study was .70.

The Family Crises Oriented Personal Evaluation Scales (F-COPES), developed by McCubbin, Larsen, and Olson (McCubbin et al., 1996), identifies the problem solving and behavioural strategies that families use in crisis situations. The focus is on two levels of interactions, namely: (1) The internal handling of problems amongst family members, and (2) the families' way of managing problems outside the boundaries of the family unit, but still influencing the family (McCubbin et al., 1996). The 30-item, 4 point Likert scale measures the participant's responses to problems instead of how families respond to difficult situations (Richmond \& 
Christensen, 2000). The scale consists of 5 subscales, (1) acquiring social support, (2) reframing, (3) seeking spiritual support, (4) mobilising social support, and (5) passive appraisal. The 5 subscales demonstrate internal consistency, ranging from .63 (passive appraisal) to .83 (acquiring social support). The construct validity has been established and the internal consistency reliability was .83 for acquiring social support, .82 for reframing, .80 for seeking spiritual support, .71 for mobilising support, and .63 for passive appraisal (McCubbin et al., 1996). The Cronbach alpha reliability coefficient in this study was: .70 for acquiring social support, .70 for reframing, .74 for seeking spiritual support; .59 for mobilising support, and .57 for passive appraisal.

The Family Time and Routine Index (FTRI) was developed by McCubbin, McCubbin and Thompson (McCubbin et al., 1996). Activities and routines that families use and maintain, as well as the value of the practices, were assessed. Family time, practices, and routine are reliable indicators of family integration and stability that include a family's ability to handle major crises (McCubbin et al., 1996). This scale consists of 30 items and 8 subscales, (1) parent-child togetherness, (2) couple togetherness, (3) child routines, (4) meals together, (5) family time together, (6) family chores routines, (7) relatives' connection routine, and (8) family management routines (McCubbin et al., 1996). Participants are required to assess on a 4-point Likert rating scale the degree (False, Mostly false, Mostly true, or True) to which each statement describes their current family situation. Additionally, an assessment of the degree to which the participant values the routine was listed (Not important, Somewhat important, Important, Very important, and Not applicable) (McCubbin et al., 1996). The internal reliability (Cronbach's alpha) of the Family Time and Routines is .88 and the validity coefficients range from .19 to .34 with criterion indices of Family functioning (McCubbin et al., 1996). The internal reliability 
coefficient (Cronbach alpha) of the Family Time and Routines Index for this study was .76 .

\section{The Family Problem Solving Communication (FPSC) questionnaire,} developed by McCubbin, McCubbin and Thompson (McCubbin et al., 1996) was used to measure two dominant patterns in family communication, which plays an important part in coping with hardships. This scale consists of 10 items with a 4-point Likert scale (0-False, 1-Mostly false, 2-Mostly true, and 3-True) which aims to measure family communication patterns. Communication patterns are recognised as positive and negative, and both play an important role in problem solving and resiliency (McCubbin et al., 1996). The scale consists of two 5-item subscales, (1) Incendiary communication which tends to exacerbate a stressful situation and (2) Affirming communication which conveys support and care, exerting a calming influence (McCubbin et al., 1996). The alpha reliability of the Family Problem Solving Communication (FPSC) instrument is .89 (Incendiary Communication .78, and Affirming Communication .86). The validity coefficient has been validated in several large-scale studies under stress. The Cronbach alpha reliability coefficient of the Family Problem Solving Communication (FPSC) instrument for this study was .82 (Incendiary Communication .77, and Affirming Communication .76).

The Family Attachment and Changeability Index 8 (FACl8) was adapted by McCubbin, Thompson and Elver (McCubbin et al., 1996). This instrument was used to measure the dependent variable (adaptation) in this study. According to the Resiliency Model the outcome of all the processes results in the level of adaptation for the family. This scale consists of 16 items which aim to measure the level of family functioning (adaptation). The 5-point Likert scale of how often the events occur, range from Never to Always. The respondent is asked to describe how often 
each item is occurring now and how often the respondent would like to see each item happening in his/her family. The scale consists of two sub-scales, (1) Attachment, determining family members' attachment to each other, and (2) Changeability, determining the flexibility of the family members in their relationship with each other (McCubbin et al., 1996). The internal reliability (Cronbach's alpha) for the youths' Attachment scale is .73 and for the Changeability scale it is .80 . The internal reliability for the parents' Attachment scale is .75 and for the Changeability scale it is .78 (McCubbin et al., 1996). The internal reliability (Cronbach alpha) for the total scale in this study was .74 .

\section{Procedure}

The 38 families identified were approached or contacted by a post graduate student in Psychology. After the aim of the research project was explained to the parents and the participating children, they were asked whether their family, represented by a parent and child would be willing to participate. Confidentiality of the information and the anonymity of the participants were reemphasised during the visit. If the family gave their permission to be interviewed, appointments were scheduled to visit that family to collect the data.

Firstly, an open-ended question of what they thought helped their family lately through stressful times was asked for both the parent and child. Once their responses to the open-ended question were obtained, the questionnaires were given to the participating parent and child. They were asked to complete the questionnaires independently in the presence of the student. Upon completion of the questionnaires some of the participants commented on the open-ended question that they have never thought of strengths in their family - something which was a very positive experience for them. The parents and children were thanked for their 
participation and the student departed. The questionnaires were scored by the student researcher, and reviewed by a fellow student after which the data were organised and prepared for statistical analysis.

\section{RESULTS}

Thirty-eight families answered an open-ended question and completed six questionnaires. A significant correlation between family attachment and changeability (adaptation) and several potential resiliency variables were found.

In the open-ended question the participants were asked to report the most important strength's which they felt helped their remarried family through the stressful period. Recovery implied responses were identified and organised into two categories: internal resources (support within the family) and external resources (support outside the family). The frequency of responses within each theme was recorded and is reported in Table 1. 
Table 1

Internal and External Coping Resources as Reported by the Parents $(N=38)$

\section{Resources}

Internal

Family Relationship and support (mutual respect, cooperation and a loving bond)

Communication (open and honest communication between family members)

Marriage Relationship (stable, realistic, working together and sexual satisfaction)

Individual characteristics (personality, positive view of life and reaching out to others)

Positive relationship with previous marriage partner and extended family

Roles and discipline (working as partners, equals and with the same ideas of discipline)

Financial resources (security and stability of income)

External

Spirituality and religion (beliefs and activities)

Social support (family, friends and community)

Professional support (e.g. psychologists and books)

\section{Frequency}

35

33

26

26

19

18

8

22

18

4

\section{Percentage}

$92 \%$

$86 \%$

$68 \%$

$68 \%$

$50 \%$

$47 \%$

$21 \%$

$58 \%$

$47 \%$

$10 \%$

Participant responses to the open-ended question indicated that within the boundaries of the remarried family, the positive relationships and support amongst the members were the primary resource that helped families to adapt in the remarried family. Spirituality and religion were reported as the primary coping resource outside the boundaries of the family. 
Pearson product-moment correlations were calculated to determine the relationships between family adaptation $(\mathrm{FACl})$ and potential resiliency variables. These correlation coefficients are presented in Table 2.

\section{Table 2}

Pearson Product-Moment Correlations between Adaptation (FACl8) and Potential Resiliency Variables

VARIABLES $\begin{aligned} & \text { PARENTS } \\
& (\mathrm{N}=38)\end{aligned} \quad \mathrm{p} \quad$\begin{tabular}{l}
$\begin{array}{l}\text { CHILDREN } \\
(\mathrm{N}=21)\end{array}$ \\
\hline
\end{tabular}

Family Hardiness Index (FHI)

Commitment - (family's sense of Internal strengths, dependability, and ability to work together)

Challenges - (family's efforts to be innovative, active to experience new things and to learn)

Control - (family's sense of being in control of family life rather than being shaped by outside events and circumstances)

\section{Total FHI score}

Family Time and Routine Index (FTRI)

(family activities and routine that they use and maintain and value the practices)

Family Problem Solving Communication (FPSC)

Incendiary Communication (pattern of family communication that is inflammatory)

Affirming Communication (patterns of family communication which conveys support and care

Relative and Friend Support (RFS)

(the family's ability to utilise relatives and friend support to manage stressors and strains)

$\begin{array}{llll}0.454^{*} & 0.004 & 0.750^{*} & 0.000\end{array}$

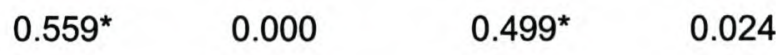

$\begin{array}{llll}0.450^{*} & 0.004 & 0.475^{*} & 0.018\end{array}$

$\begin{array}{llll}0.684^{*} & 0.000 & 0.769^{*} & 0.000\end{array}$

$\begin{array}{llll}0.489^{*} & 0.001 & 0.712^{*} & 0.000\end{array}$

$\begin{array}{llll}-0.484^{*} & 0.001 & -0.576^{*} & 0.000\end{array}$

$\begin{array}{llll}0.526^{*} & 0.000 & 0.719^{*} & 0.000\end{array}$

$\begin{array}{llll}-0.118 & 0.480 & 0.441^{*} & 0.030\end{array}$

(table continues) 
Table 2 (continued)

VARIABLES

Social Support Index (SSI)

(the degree to which families find emotional, esteem, and network support with in their communities

Family Crisis Oriented Personal

Evaluation Scales (F-COPES)

Reframing - (family's capability to redefine stressful events in order to make them more manageable)

Passive appraisal - (family's ability to accept problematic issues minimising reactivity)

Social support - (family's ability to actively engage in acquiring support from relatives, friends, neighbours and extended family)

Spiritual and religious support (family's ability to acquire spiritual/religious support)

Mobilisation - (family's ability to acquire community resources and accept help from others)

\section{PARENTS}

( $N=38)$

$0.327^{\star}$

0.045

0.282

0.181

CHILDREN p

$(\mathrm{N}=21)$

$0.007 \quad 0.966 \quad 0.474^{*} \quad 0.019$

$-0.067$

0.686

0.274

0.194

$-0.119$

0.503

$0.633^{*}$

0.000

0.244

0.139

0.207

0.329

0.085

0.607

$0.461^{*}$

0.023

Parents' age

0.073

0.668

0.199

0.374

Years married

0.046

0.748

0.206

0.344

Income

0.110

0.522

$0.435^{*}$

0.037

Children's age

0.066

0.022

0.922

${ }^{*} \mathrm{p} \leq 0.05$

The results indicate that for the parents, family adaptation (FACI8 total scores) is positively correlated to the following variables: (1) the ability to have a sense of control over outcomes in life by having a active orientation in adjusting to and managing stressful situations (Family Hardiness Index: global score), (2) activities and routines that helps the family in spending time together and creating 
togetherness (Family Time and Routine Index), (3) family communication that is affirming conveying care and support as well as less incendiary communication that tends to exacerbate a stressful situation, and (4) social support in the community and the families integration in the community.

Results indicated that for the children, family adaptation positively correlated with the following variables: (1) the ability to have a sense of control over outcomes in life by having an active orientation in adjusting to and managing stressful situations (Family Hardiness Index: total score), (2) activities and routines that helps the family in spending time together and creating togetherness (Family Time and Routine Index), (3) family communication that is affirming conveying care and support as well as less incendiary communication that tends to exacerbate a stressful situation (Family Problem Solving Communication), (4) support from family and friends (Relatives and Friend Support Index), and (5) Internal and external handling of problems by redefining stressful events and acquiring and accepting social support (Family Crisis Oriented Personal Evaluation Scale: reframing, social support and mobilisation subscale).

A best-subset regression analyses were executed for both the parents and children. The results are shown in Table 3 and Table 4. 
Table 3

Regression Analysis for Family Adaptation (FACI8) as Dependent Variable vs. Potential Resiliency Variables (parents) $(N=38)$

\begin{tabular}{llc}
\hline VARIABLES & B & p-level \\
\hline $\begin{array}{l}\text { Family Problem Solving Communication (FPSC) } \\
\quad \text { Affirming communication subscale }\end{array}$ & 0.55 & \\
Family Crisis Oriented Personal Evaluation Scales & & \\
(F-COPES) & & 0.02 \\
$\quad$ Mobilisation subscale & -0.35 & \\
Family Crisis Oriented Personal Evaluation Scales & & \\
(F-COPES) & & \\
$\quad$ Passive appraisal subscale & -0.35 \\
Family Crisis Oriented Personal Evaluation Scales \\
$\begin{array}{l}\text { (F-COPES) } \\
\text { Reframing subscale }\end{array}$ \\
$\begin{array}{l}\text { Family Hardiness Index (FHI) } \\
\quad \text { Total }\end{array}$ \\
$\begin{array}{l}\text { Family Time and Routines Index (FTRI) } \\
\text { Total }\end{array}$ \\
\hline
\end{tabular}

The identified variables declared $68 \%\left(R^{2}=0.68\right)$ of the variance in FACI8 scores. The following variables are, according to the parents, best predictors for family adaptation (FACI8):

- Family communication that is affirming conveying care and support (Family Problem Solving Communication: affirming subtest),

- The ability to have a sense of control over outcomes in life by having a active orientation in adjusting to and managing stressful situations (Family Hardiness Index: Total), 
- Internal and external handling of problems by redefining stressful events, acquiring and accepting social support (Family Crisis Oriented Personal Evaluation Scale: reframing and mobilisation subscale).

Table 4

Regression Analysis for Family Adaptation (FACl8) as Dependent Variable vs. Potential Resiliency Variables (children) ( $n=21)$

\begin{tabular}{llc}
\hline VARIABLES & B & p-level \\
\hline $\begin{array}{l}\text { Family Problem Solving Communication (FPSC) } \\
\quad \text { Affirming communication subscale }\end{array}$ & 0.92 & 0.00 \\
$\begin{array}{l}\text { Family Crisis Oriented Personal Evaluation Scales } \\
\text { (F-COPES) }\end{array}$ & & \\
$\quad$ Social support subscale & 0.29 & 0.03 \\
$\begin{array}{l}\text { Family Crisis Oriented Personal Evaluation Scales } \\
\text { (F-COPES) } \\
\quad \text { Reframing subscale }\end{array}$ & & \\
Family Time and Routines Index (FTRI) \\
$\quad$ Total
\end{tabular}

The identified variables declared $74 \%$ of the variance in $F A C l 8$ scores $\left(R^{2}=0.74\right)$. The following variables are, according to the children, best predictors for family adaptation (FACl8):

- Family communication that is affirming conveying care and support (Family Problem Solving Communication: affirming subtest)

- External handling of problems by acquiring and accepting social support (Family Crisis Oriented Personal Evaluation Scale: social support subscale)

- Activities and routines that helps the family in spending time together and creating togetherness (Family Time and Routine Index) 
One p-value was not significant, which predicts that the variable played less of a role than the others predictors.

\section{DISCUSSION}

The aim of this study was to explore how aspects of family resilience are associated with the adjustment and adaptation of a reconstituted family after remarriage. Family resilience determines the extent to which a family has returned to or exceeded prestressor levels of functioning at some point subsequent to the stressor. Several researchers observed how families moved from crises to successful adaptation and uncovered family resources that facilitated adaptation following a major crisis (Conger \& Conger, 2002; McCubbin, 1988; McCubbin \& McCubbin, 1988; McCubbin, Balling, Possin, Friedrich \& Bryne, 2002; Mederer, 1999; Patterson, 2002;). In this study the following variables correlated significantly with family adaptation and are consequently discussed as indicators of family resilience.

The most important coping resource that was identified from the responses on the open ended question was internal family relationships and support amongst family members. Ninety two percent of the families indicated that the relationship amongst them contributed towards their resilience. This is in agreement with Visher et al. (2003) and Walsh (2003a) who found that step relationships are of great importance if step families want to be successful. In troubled times mutual support, commitment and collaboration strengthened resilience (Walsh, 2003a). When families are able to collaborate in problem solving ideas, it encourages other ideas, choices and everyone can voice his/her opinion. According to Walsh (1998a) this openness in trying new solutions to meet challenges builds well-functioning families. When families believe they can turn to one another and when they take active 
interest in what is important to each other, it becomes a "holding environment" standing against adversity (Walsh, 1998a).

The second most important resource reported by the family was that communication was open and honest amongst them. Eighty six percent of the participating families reported that communication within families fostered resilience by encouraging open emotional expression, clarifying crisis situations and collaboration in problem solving. Research indicates that when family members interact with each other frequently in a positive honest manner, communication is strengthened (Silberberg, 2001). Through communication families create a sense of meaning, maintaining harmony and coping strategies (McCubbin et al., 1997). Results obtained from the Family Problem Solving Communication (FPSC) questionnaire affirm the supportive and adaptive value of open and honest communication (see Table 2). Strong families are able to adapt to changing circumstances and have a positive attitude toward the challenges of family life. They deal with these challenges by means of communication - talking things through with each other; supporting each other in times of need and/or seeking outside support when it is beyond the family's capability to deal with the situation. (Silberberg, 2001).

As in first marriage families, a strong couple relationship is as important in successful remarried families. Sixty eight percent of the families identified a stable marriage relationship as an important resilience factor (see Table 1). This is in agreement with Walsh (1998a) indicating that research has emphasised that couples function best when supported by each other. According to Visher et al., (2003) strong and stable couple relationships bring happiness to the adults and reduce anxiety in children regarding another parental break-up. Furthermore it creates an atmosphere where relationships could be warm and supportive. 
Both parents and children identified family hardiness as a resiliency factor (see Table 2). Furthermore, both parents and children identified commitment, challenge and control (Family Hardiness Index) as a buffer against crises. Family hardiness refers to the internal strengths of the family as a unit, characterised by a sense of commitment, an active orientation towards managing stressful situations and having a sense of control over hardships in life (McCubbin et al., 1996). This implies that adjusting to hardship and working together, confronting their challenges as a unit, gives the family the belief that they are in control of their lives and adaptation can then take place.

Fifty eight percent of the families identified spirituality, religious beliefs and activities as an important coping resource (see Table 1). Spirituality is described as a transcendent understanding of the meaning and purpose of life (Berg-Cross, 1997). According to McCubbin et al. (1996) families use spirituality to frame the crisis situation in terms of shared beliefs and goals as a way to achieve harmony. The marriage and the family provide the space for spiritual discovery, development and become the context in which religious values are played out. Furthermore, according to Walsh (1998b), religious rituals provide place in the chaos of reality. Although the above indicates strong evidence for spirituality and religious beliefs as a resilience factor, these factors were not confirmed by the results of the quantitative questionnaires used in this study (see Table 2).

It is apparent that social support could be seen as a reliable indicator of family resilience, since forty seven percent of the families identified it as a coping resource (see Table 1). Data obtained with the Social Support Index (SSI) and the Family Crises Oriented Persona Evaluation Scale (F-COPES) that is the coping style of acquiring social support from relatives and friends confirmed the evidence of social 
support as an important resilience factor (see Table 2). According to McCubbin et al. (1997), social support is a protective as well as a recovery factor. In times of trouble social networks are able to offer emotional and practical support.

In crises, family time and routine are disrupted and replaced by the families' problems and the hardship accompanying these (McCubbin et al., 1997). Both the parents and children identified family time and routine as a resilience factor (see Table 2). Family time and routine refers to family practices, such as spending quality time together, having meals together, and developing patterns of behaviour that create stability and harmony (McCubbin et al., 1997).

Although no questionnaire was used in determining individual characteristics, sixty eight percent of the families identified individual personality traits, such as a positive outlook on life, reaching out to others, and a strong personality as an important resilience factor (see Table 1). According to Walsh (1998b) vital factors for resilience is a positive outlook, optimism and hope to withstand adversity. This study focuses on the combination of individual and relational patterns within families as resilient factor in times of hardship. Although the above indicates strong evidence of personal attributes strengthening family resilience, these factors were not measured quantitatively in this study. Future studies could focus on individual and relational factors when studying family resilience.

Fifty percent of the families in this study identified relationships with previous marriage partners and the extended families as a buffer against hardship (see Table 1). Both adults and children experience a sense of loss during a divorce. If remarried families wish to be well-functioning and sensitive to the children's needs, maintaining bonds with the extended family would allow them to adjust to change (Visher et al., 2003). When open boundaries and connections across households 
are encouraged, resilience of stepfamilies and children is the strongest (Walsh, 1998a). Furthermore, when children's needs to bond with both parents are understood by the subsequent partners and they are not threatened by the good relationship between the ex-partners, this could be very helpful for the family.

Forty seven percent of the families indicated that working as partners on the same disciplinary ideas and clearly defined roles, would foster resilience in the remarried families. Parental roles are often a source of conflict between spouses and, even more so, within remarried families. Children affect their parents and, therefore, it is important for the parents to remain emotionally open and cooperative with one another (Berg-Cross, 1997). When all the parents are able to form a "parenting coalition", in sharing the parental responsibilities, fewer intense loyalty conflicts arise (Visher et al., 2003).

Although the family income was not mentioned as a resource by any of the parents, and no correlation was found between family income and family adaptation according to the parents, the children's results show that a definite association between family income and adaptation exist (Tables 1 and 2).

It is proposed that the most important resilience factors identified in this study, through qualitative and quantitative measures, include (1) family relationships and support (mutual respect, cooperation and a loving bond), (2) family communication that is affirming conveying care and support as well as less incendiary communication that tends to exacerbate a stressful situation (3) the ability to have a sense of control over outcomes in life by having a active orientation in adjusting to and managing stressful situations (4) activities and routines that helps the family in spending time together and creating togetherness, (5) strong marriage relationship (consisting of clearly defined roles, equality and support for each other) (6) support 
from family and friends, (7) internal and external handling of problems by redefining stressful events and acquiring and accepting social support, (8) spirituality and religion that provides meaning and purpose beyond the crisis situation.

This study contributes by altering the deficit-based lens from viewing remarried families as damaged, to viewing them as challenged by adversity. An increasing number of family researchers are opting for a strength approach in their family and community research. Better than expected, human development under adverse conditions expanded our understanding and indicates that the family resilience perspective has much to offer the family science discipline (Roosa, 2000). Through exploring resilience variables in remarried families, the capacity of other remarried families to master adversity is strengthened. Research on resiliency is thus significant, because both protection and vulnerability processes are identified and explain why and how resiliency is exhibited (Markstrom, Marshall \& Tryon, 2000). Resilience factors in remarried families could well become the map to guide prevention and intervention efforts (Walsh, 2002). "Resilience seems to capture the human need to live, to search, and to find closure and healing - to find health again, a never-ending journey" (Riolli et al., 2002, p.1624).

The findings of this study provide insight into protective and recovery factors employed by remarried families. These results could be used for future resilience studies. Limitations of this study are that families' cultural background was not taken into account. It is imperative for future research to use samples from more clearly defined study populations. Furthermore, the relevant sample represented only a small sector of the diverse remarried South African population. 


\section{REFERENCES}

Berger, R. (1995). Three types of stepfamilies. Journal of Divorce \& Remarriage, 24(1/2), 35-49.

Berg-Cross, L. (1997). Couples therapy. California: Sage Publications, Inc.

Conger, R.D., \& Conger, K.J. (2002). Resilience in Midwestern families: selected findings from the first decade of a prospective, longitudinal study. Journal of Marriage \& Family, 64(2), 361-374.

Cooper, C.L., \& Payne, R. (1991). Personality and stress: individual differences in the stress process. New York: John Wiley \& Sons.

Der Kinderen, S., \& Greeff, A.P. (2003). Resilience among families where a parent accepted a voluntary teacher's retrenchment package. South African Journal of Psychology, 33(2), 86-94.

Derma, S. (1999). The experience of divorce and separation in the family: a dynamic systems perspective. In E. Frydenberg (Ed.). Learning to cope: developing as a person in complex societies. (pp. 150-171). New York: Oxford University Press.

Fine, M.A., \& Schwebel, A.I. (1992). Step parents stress: a cognitive perspective. Journal of Divorce \& Remarriage, 17(1/2), 1-15.

Ganong, L.H., \& Coleman, M. (2002). Family resilience in multiple contexts. Journal of Marriage and Family, 64(2), 346-349.

Golby, B., \& Bretherton, I. (1999). Resilience in post divorce mother-child relationships. In H. McCubbin, E. Thompson, A. Thompson, \& J. Furtell. The dynamics of resilient families, (Eds.) (pp. 237-269). California: Sage Publications,

Gold, J.M., Bubenzer, D.L., \& West, J.D. (1993). Differentiation from ex-spouses and stepfamily marital intimacy. Journal of Divorce \& Remarriage, 19(3/4), 83-95. 
Greeff, A.P., \& Human, B. (2004). Resilience in families in which a parent has died. The American Journal of Family Therapy, 32, 27-42.

Greeff, A.P., \& Van der Merwe, S. (2004). Variables associated with resilience in divorced families. Social Indicators Research, 68(1), 59-75.

Hawley, D. (2000). Clinical implications of family resilience. The American Journal of Family Therapy, 28, 101

Hawley, D., \& DeHaan L. (1996). Toward a definition of family resilience: Integrating lifespan and family perspective, Family Process 35, 283.

Hetherington, E.M. (1989). Coping with family transitions: Winners, losers, and survivors. Child Development, 60 p. 1-14.

Hetherington, E.M., \& Elmore, A.M. (2003). Risk and resilience in children coping with their parents' divorce and remarriage. In S. Luthar (Ed.). Resilience and Vulnerability: Adaptation in the context of childhood adversities (pp. 182-212). Cambridge: Cambridge University Press.

Kalter, N. (1990). Growing up with divorce: helping your child avoids immediate and later emotional problems. New York: The Free Press, a Division of Macmillan, Inc.

Lauer, R.H. (1989). Social problems and the quality of life ( $4^{\text {th }}$ ed.). Dubuque:lowa: Wm. C. Brown Publishers.

Luthar, S., Cicchetti, D., \& Becker, B. (2000). The construct of resilience: a critical evaluation and guidelines for future work. Child Development, 71(3), 543-562.

Markstrom, C.A., Marshall, S.H., \& Tryon, R.J. (2000). Resiliency, social support, and coping in rural low-income Appalachian adolescents from two racial groups. Journal of Adolescence, 23, 693-703.

Masten, A. (2001). Ordinary magic: resilience process in development. American psychologist, 56, 227-238. 
Masten, A.S., \& Powell, J.L. (2003). A resilience framework for research, policy and practice. In S. Luthar (Ed.). Resilience and vulnerability: adaptation in the context of childhood adversities, (pp. 1-25). Cambridge: Cambridge University Press.

McCubbin, H.I., \& McCubbin, M.A. (1988). Typologies of resilient families: emerging roles of social class and ethnicity. Family Relations, 37, 247-254.

McCubbin, M. (1988). Family stress resources and family types: chronic illnesses in children. Family Relations 37, 203-210.

McCubbin, H.I., Thompson, A.I., \& McCubbin, M.A. (1996). Family assessment: resiliency, coping and adaptation - inventories for research and practice. Madison: University of Wisconsin Publishers.

McCubbin, H.I., McCubbin, M.A., Thompson, A.I., Han, S., \& Chad, T. (1997). Families under stress: what makes them resilient. AAFCS Commemorative Lecture. Retrieved 5 August 2004 from the World Wide Web:

http://www.cyfernet.org/research.resilient.html

McCubbin, M., Balling, K., Possin, P., Friedrich, S., \& Bryne, B. (2002). Family resilience in childhood cancer. Family Relations, 51(2), 103-112.

McGoldrick, M., \& Carter, B. (1989). Forming a remarried family. In B. Carter \& M. McGoldrick (Eds.), The changing family life cycle: a framework for family therapy. $\left(2^{\text {nd }}\right.$ edition). Boston, Mass: Allyn and Bacon.

Mederer, H. (1999). Surviving the demise of a way of life. In H. McCubbin, E. Thompson, A. Thompson, J. Furtell (Eds.). The dynamics of resilient families, (pp. 203-235), London: Sage Publications.

Messinger, L. (1984). Remarriage: a Family affair. New York: Plenum Press.

Norman, E. (2000). Resiliency enhancement: putting the strength perspective into social work practice. New York: Columbia University Press. 
Patterson, J. (2002). Integrating family resilience and family stress theory. Journal of Marriage \& Family, 64, 349.

Reivich, K., \& Shatte, A. (2003). The resilience factor: seven essential skills for overcoming life's inevitable obstacles. New York: Broadway Books.

Richmond, L.S., \& Christensen, D.H. (2000). Coping strategies and post divorce health outcomes. Journal of Divorce \& Remarriage, 34(1/2), 41-56.

Riolli, L., Savicki, V., \& Cepani, A. (2002). Resilience in the face of catastrophe: optimism, personality, and coping in the Kosovo crisis. Journal of Applied Social Psychology, 32(8), 1604-1627.

Robinson, H. (2000). Enhancing couple resiliency. In E. Norman (Ed.). Resiliency enhancement: putting the strengths perspective into social work practice (pp. 102127). New York: Columbia University Press.

Roosa, M.W. (2000). Some thoughts about resilience versus positive development, main effects versus interactions, and the value of resilience. Child Development, 71(3), 567-569.

Shirley, K.J. (2000). Resilient marriages: from alcoholism and adversity to relationship growth. Oxford: Rowman \& Littlefield Publishers, Inc.

Silberberg, S. (2001). Searching for family resilience. Family Therapy, 28, 101.

Silliman, B. (1994). Resiliency research review: conceptual \& research foundations. National Network for Family Resiliency. Retrieved September 24, 2004 from the World Wide Web: http://www.cyfernet.org/research/resilreview.html

Statistics South Africa. (2001). South African Statistics 2001. Pretoria: Statistics South Africa.

Swenson, D. (1997). A model of the remarried family. Journal of Divorce \& Remarriage, 27(1/2), 159-185. 
Visher, E.B., \& Visher, J.S. (1990). Dynamics of successful stepfamilies. Journal of Divorce \& Remarriage. 14(1), 3-12.

Visher, E.B., Visher, J.S., \& Pasley, K. (2003). Remarriage families and step parenting. In F. Walsh (Ed.) Normal family processes: growing diversity and complexity (pp. 153175). New York: Guilford Press.

Von Eye, A., \& Schuster, C. (2000). The odds of resilience. Child Development, 71(3), 563-566.

Waldren, T., Bell, N.J., Peek, C.W., \& Sorell, G. (1990). Cohesion and adaptability in post-divorce remarried and first married families: relationships with family stress and coping styles. Journal of Divorce \& Remarriage, 14(1), 13-28.

Walsh, F. (1996). Concepts of family resilience: crisis and challenge. Family Process, 35(3), 261-281.

Walsh, F. (1998a). Strengthening family resilience. New York: Guildford Press.

Walsh, F. (1998b). Belief, spirituality and transcendence: keys to family resilience. In M. McGoldrick (Eds.). Re-visioning family therapy: race, culture and gender in clinical practice (pp. 62-77). New York: Guildford Press.

Walsh, F. (2002). A family resilience framework: Innovative practices applications, Family Relations, 51,130.

Walsh, F. (2003a). Family resilience: A framework for clinical practice. Family Process, 41(1), 1-18.

Walsh, F. (2003b). Normal family processes: growing diversity and complexity ( $3^{\text {rd }}$ ed.). New York: Guildford Press.

Whiteside, M.F. (1982). Remarriage: a family development process. Journal of Marital and Family Therapy, 8, 59-68. 